\title{
A Comparison of Locus of control and General English Achievement in Students of Medicine and Theology
}

\author{
Seyyed Ehsan Golparvar \\ University of Tehran, Iran
}

\section{İntroduction}

Delving into the maze of L2 acquisition necessitates examining factors lrellated to individual differences (IDs) in learners (Ellis, 2008) which are different from one person to another (Dörnyei, 2005) and deal with anything which marks a person as a distinct human being (De Road, 2000). Studies conducted in this field have highlighted IDs to be reliable predictors of L2 success (Dörnyei, 2005). Early studies of IDs had an either-or approach; they tended to classify learners as good and weak, intelligent and dull, and motivated and unmotivated (Horwitz, 2000). Recently, more research projects have focused on explaining why some learners are more successful than others. Robinson (2002) and Dörnyei (2005) both put language aptitude, motivation, personality, and anxiety on their list as the main factors in the realm of individual differences. Oxford and Ehrman (1993) maintained that teachers should spot IDs among their students and take them into account in order to work out the most effective instructions. Research in this field has mainly focused on particular learners' characteristics and their measurement rather than showing some illuminating guide lines to help learners in the process of learning, how to assist them to take charge of their own learning, and how to mediate their learning (Williams \& Burden, 1997). In general, major points regarding IDs research can be summarized this way:

1. Research in the IDs area is grounded on a theory of learning that considers individuals' behaviors as being influenced by a set of fixed traits or attributes.

2. The findings are of limited practical value since they do not give us insight into how teachers can help learners to become effective learners. (Williams \& Burden, 1997, p. 95)

Therefore, Williams and Burden (1997) adopted a constructivist approach including the individuals' main contributions to the learning situation is needed 
because: (a) such a theory enables us to highlight the uniqueness of individuals and help teachers to see what they have in common, (b) it helps us to see how individuals change rather than how they stay the same,

3. It enables teachers to help learners take control of their own learning, and

4. It focuses on individuals' perceptions of themselves as learners.

According to constructivism, people's understanding of the world is gradually reshaped as they adapt their knowledge to new information. The way in which individuals perceive the world and themselves has a vital role in their learning. Therefore, it is of importance to focus on how learners perceive themselves as language learners, what effects their personal

views bear on their learning processes, and how teachers can assist them in making sense of their learning that is personal to them, rather than concentrating on how learners are different from each other or gauging these differences. One important domain which is in association with the way in which learners perceive themselves is Locus of Control (LOC). This study is aimed at investigating the relationship between this affective variable and GE course achievement among two groups of university students.

\section{Literature Review}

In many countries of the world where English is learned as a foreign language, university students are obliged to pass a certain number of English courses as academic requirements. General English is prerequisite for Special English courses offered to university students. In Iran, GE is characterized by a commitment to pass three credits in a domain-specific fashion in which reading skill is the only skill which is taught. GE courses essentially consist of semi-specific texts designed for students aiming to gain expertise in different academic fields. However, the extent to which these courses result in optimal learning output has been partially examined by several researchers (e.g., Ghonsooly and Pishghadam, 2008).

Most of the studies done in this area have leveled criticism on the textual and instructional objectives of GE courses and have remained oblivious to learner characteristics as a relevant and indis pensable factor in GE achievement. Locus of control is a psychological construct which has been treated as influential and important in achieving learning goals as instructional and textual factors. There has been a large body of research dealing with LOC in studies focusing on psychological differences (e.g., Anderman, \& Midgly, 1997; Biaggio, 2004). LOC 
has been divided into two types: internal and external. People who ascribe their achievements and failures to internal causes such as their efforts and abilities and feel really responsible for the things happening to them are called internals. Individuals who attribute their success and failures to external influences out of their control like fate and luck are labeled externals (Findley \& Cooper, 1983).

The concept of LOC is closely linked to attribution theory, which is the process through which the causes of the events can be explained (Jarvis, 2005). Weiner (1979), who developed this theory first referred to four important sets of attributions for the individuals' perceived success and failure in their life: (a) ability, (b) effort, (c) success, and (d) the level of difficulty of the tasks they are involved in.

Later Weiner (1992) identified three dimensions regarding the nature of attributions of success and failure:

1. Locus of control: the extent to which people believe they can take control of events.

2. Stability: whether success or failure have stable causes (effort or task difficulty) or unstable ones (luck, mood).

3. Controllability: the extent to which elements or events are within the individuals' control or not.

Learners who have internal LOC tend to attribute results to their own actions or efforts when they are controllable; otherwise, they are attributed to ability and mood which are not controllable. On the contrary, externalizers attribute their success or failure to features of the situation or external stable cases like task difficulty in case they are uncontrollable; otherwise, they may be attributed to unstable causes like teacher bias.

Several researchers have shown that internal control orientation is related to higher levels of academic achievement. For example, Bender (1995) held that failures followed by persistent attempts may lead to external locus of control and this may consequently lead to lower degrees of motivation for study. Externalizers may percieve that their efforts are fruitless and that it is not important to work hard since they see failures as their fate (Bender, 1995). Basgall and Snyder (1988) asserted that externals do not mind their poor performance and this does not hurt their self-esteem since they avoid the possible damage caused by their lack of abilities through ascribing their failures to chance, destiny, or other peoples' faults. This dismisses the belief that they are inadequate but the point is that such a view 
lowers their motivation (Basgall \& Snyder, 1988). Phares (1979) mentioned that individuals who attribute their failure to internal factors accept their faults as personal and relate them to lack of skills. However, those with an external locus of control escape personal inadequacy (Phares, 1979), hence reducing negative feelings of failure and are unlikely to see a promising future (Anderman and Midgley, 1997). However, those with an internal locus of control are likely to consider a bright future for themselves by trying harder and making more efforts which may lead to a raise in the ir grades (Noel, et al., 1987). Examining the behavior of internals and externals in performing tasks, Kernis (1984) found that internals were interested in continuing the tasks they performed successfully whereas externals avoided working on a particular learning task and preferred to work on other tasks. This finding was partially in line with Lonky and Reiman's (1980) research in which their internal students spent more time on performing tasks than externals.

There are some studies on the relationship between LOC and academic success in general and L2 achievement in particular. Gifford, Prieceno-Perriott, and Miamzo (2006) found that students' GPA is correlated with internal LOC. Galjes and D'Silva (1981) reported that students who obtained higher grades consider themselves as internally oriented. Similarly Wood, Saylor, and Cohen (2009) concluded that external control orientation can have a negative effect on academic achievement in nursing students. The concept of LOC has not been fully explored in the EFL context of Iran. Ghonsooly and Elahi (2010) found that there is a high correlation between university students' LOC and their scores in their General English scores in their ESP courses. Hosseeini and Elahi also found that LOC is a predictor of $\mathrm{L} 2$ reading achievement.

Research has also examined the association between locus of control and anxiety indicating internals feel more state-anxiety than externals in situations related to "luck" whereas externals showed to have more state-anxiety in "ability" situations (Biaggio, 2004). In a more related investigation, the relationship between locus of control, procrastination and anxiety (Carden et.al., 2004) were explored in which internals experienced higher academic procrastination and test anxiety than externals .

The effect of LOC on General English achievement of Iranian university students is not widely researched. Ghomsooly and Elahi (2010) studied the effect of this ID variable on GE course achievement of students of Engineering, Sciences, and Humanities. This study aims at investigating this effect among students of Medicine and students of Theology. Hence, the present research tries to answer the following questions: 
1. Is there any significant relationship between university students' LOC and their GE achievement?

2. Is there any significant difference in GE achievement between students of Medicine and students of Theology?

3. Is there any significant difference in LOC between students of Medicine and students of Theology?

\section{Method}

\section{Participants}

The participants of this study are two groups of undergraduate students. The first group includes fifty students of Medic ine studying at Medical Sciences University of Mashhad. The second group consists of fifty students of Theology studying at Ferdowsi University of Mashhad. On the whole, the sample of this study comprised 100 university students whose participation was quite voluntary. The participants are both males and females. All the students are native speakers of Persian.

\section{Instruments}

- Internal Control Index

The Persian version of the Internal Control Index (Ghonsooly \& Elahi, 2010) was used in this study to measure the participants' locus of control. The English version of the Internal Control Index (Duttwie ler, 1984) was developed to measure where a person expects to gain reinforcement. This scale has twenty eight five-point Likerttype items that produces a possible range of scores from twenty eight to 140 . Higher scores represent internal LOC and lower scores represent external LOC. Ghonsooly and Elahi (2010) calculated Cronbach's alpha to check the reliability of the translated questionnaire. The result was a coefficient of 0.83 . In order to ensure the construct validity of the instrument, they used a principle component analysis which yielded eight factors with eight values greater than one. The factors include the need to be encouraged, reliance on one's attitude, interest in administrative jobs, effort to reach desirable goals, undecidedness, the need to consult for making decisions, being responsible for desirable events, and self-expression (Hosseini \& Elahi, 2010).

- Interview

An unstructured interview with 6 students of each group was conducted on the amount of time and effort they devoted to GE tasks and homework. In addition, their attitude towards GE courses, their attempts to achieve higher scores in these 
courses and their motivation were explored. Each interview took about 20 minutes. These students were quite willing to be interviewed.

\section{Data collection and Analysis}

After seeking permission from the instructors, the researcher visited the classes in order to administer the questionnaires. Before distributing the questionnaire to the participants, they were informed briefly about the purposes of the study and the possible implications its results may have for GE teachers and university students. The students were made certain that the results remain confidential. The questionnaires were administered in one session under standard conditions. The directions of the questionnaires were Persian; however, the researcher explained them once more so that participants would have a clear understanding of what they were supposed to do. The guideline for scoring the Internal Control Index is available in Hosseini and Elahi (2010). They answered the questionnaire in about 20 minutes. Ten days after the final exam of GE courses, the participants' GPA of all their GE exams during the semester was provided by the ir teachers. The data collected were put into Statistical Package for Social Sciences (SPSS) to be analyzed. The Pearson correlation formula was used to answer the first research question. Independent t-test was calculated to answer the second and the third questions.

\section{Results}

This section includes two parts. The first part reports quantitative results of the study. Pearson correlation coefficient was measured to answer the first research question. Independent t-test was applied to find an answer to the second and third questions. The second part of the results section presents the results of the interviews conducted by the researcher.

The first research question deals with the relationship between students' LOC and their GE scores. Pearson correlation coefficient was used to answer this question. Table 1 shows the association between the two variables.

Table 1: The relation between LOC and GE score

\begin{tabular}{|l|l|l|l|}
\hline \multicolumn{2}{|l}{ Correlations } \\
\hline & & LOC & GE score \\
\hline LOC & Pearson Correlation & 1 & $.736^{* *}$ \\
\hline \multirow{3}{*}{} & Sig. (2-tailed) & & .000 \\
\cline { 2 - 4 } & N & 100 & 100 \\
\hline
\end{tabular}




\begin{tabular}{|l|l|l|l|}
\hline \multicolumn{3}{|l|}{ Correlations } \\
\hline \multirow{3}{*}{$\begin{array}{l}\text { GE } \\
\text { score }\end{array}$} & Pearson Correlation & $.736^{* *}$ & 1 \\
\cline { 2 - 4 } & Sig. (2-tailed) & .000 & \\
\cline { 2 - 4 } & $\mathrm{N}$ & 100 & 100 \\
\hline \multirow{3}{*}{$* *$. Correlation is significant at the 0.01 level (2-tailed). } \\
\hline
\end{tabular}

As shown in Table 1, the correlation is significant $(\mathrm{r}=.73 \mathrm{p}<.05)$. Thus there is a significant positive association between university students' GE scores and their LOC. The higher LOC orientation of university students is, the higher their GE scores are.

In order to seek an answer to the second research question concerning the possible significant difference between students of Medicine and students of Theology in terms of LOC, first LOC mean scores of both group are compared. Table 2 shows mean scores of the two groups.

Table 2: Group statistics: A comparison of LOC means scores in the two groups of students

\begin{tabular}{|l|l|l|l|l|l|}
\hline \multicolumn{6}{|l|}{ Group Statistics } \\
\hline & Group & $\mathrm{N}$ & Mean & Std. Deviation & Std. Error Mean \\
\hline \multirow{2}{*}{ OOC } & Medic ine & 50 & 103.36 & 8.73594 & 1.23545 \\
\cline { 2 - 6 } & Theology & 50 & 76.1000 & 10.36724 & 1.46615 \\
\hline
\end{tabular}

As shown above, the LOC mean score of the students of Medicine is 103.38, and that of students of Theology is 76.1. Table 3 demonstrates whether this difference in mean scores is significant or not.

As exhibited in Table 3, the p value of .000 is much lower than .05. This means that the difference between the means is statistically significant. Hence, students of Medicine have higher scores in LOC than students of Theology. In other words, students of Medicine are more internally controlled.

Similarly, to find an answer to the third research question concerning the possible significant difference between students of Medicine and those of Theology in terms of GE score Independent sample T-Test formula was calculated. Table 4 presents the GE mean scores of the two groups of students. 
Table 3: Determining the significance of the mean score diffe rence in LOC

Independent Samples T-Test

\begin{tabular}{|c|c|c|c|c|c|c|c|c|c|}
\hline \multicolumn{6}{|c|}{ t-test for Equality of Means } & \multicolumn{2}{|c|}{$\begin{array}{l}\text { Levene's Test for } \\
\text { Equality of Variances }\end{array}$} & & \\
\hline $\begin{array}{l}95 \% \text { Confidence } \\
\text { Interval of the } \\
\text { Difference }\end{array}$ & $\begin{array}{l}\text { Std. Error } \\
\text { Mean } \\
\text { Difference }\end{array}$ & & $\begin{array}{l}\text { Sig. (2- } \\
\text { tailed) }\end{array}$ & $\mathrm{df}$ & $\mathrm{t}$ & Sig. & $\bar{F}$ & & \\
\hline Upper & Lower & Difference & & & & & & & \\
\hline $\begin{array}{l}31.06476 \\
31.06613\end{array}$ & $\begin{array}{l}23.45524 \\
23.45387\end{array}$ & $\begin{array}{l}1.91727 \\
1.91727\end{array}$ & $\begin{array}{l}27.26000 \\
27.26000\end{array}$ & $\begin{array}{l}.000 \\
.000\end{array}$ & $\begin{array}{l}98 \\
95.261\end{array}$ & $\begin{array}{l}14.218 \\
14.218\end{array}$ & .269 & 1.236 & $\begin{array}{l}\text { Equal variances } \\
\text { assumed LOC } \\
\text { Equal variances not } \\
\text { assumed }\end{array}$ \\
\hline
\end{tabular}

Table 4: Group statistics: A comparison of GE means scores in the two groups of students

\begin{tabular}{|l|l|l|l|l|l|}
\hline \multicolumn{6}{|l|}{ Group Statistics } \\
\hline \multirow{3}{*}{ score } & Group & $\mathrm{N}$ & Mean & Std. Deviation & Std. Error Mean \\
& Medic ine & 50 & 17.9000 & .88208 & .12474 \\
\cline { 2 - 6 } & Theology & 50 & 16.3450 & 1.44180 & .20390 \\
\hline
\end{tabular}


According to Table 4, the GE mean score of students of Medicine is 17.90, and that of students of theology is 16.34 . Table 5 determines whether this difference is significant or not.

Table 5: Determining the significance of the mean score difference in GE score

\section{Independent Samples T-Test}

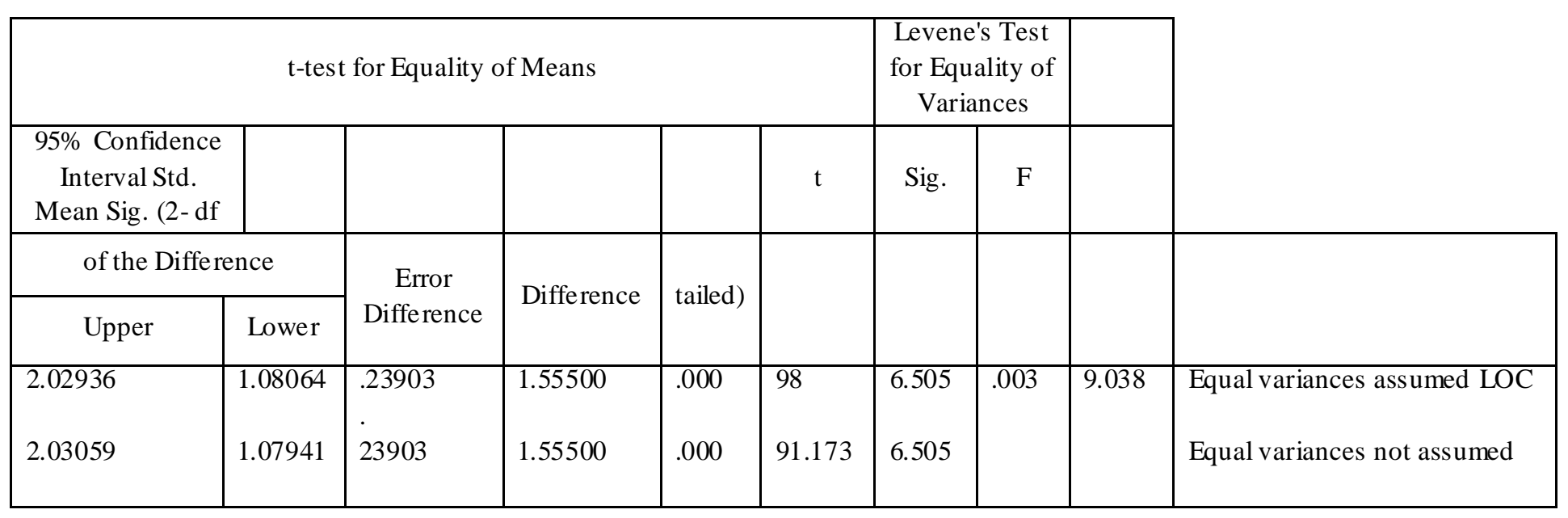


Based on Table 5, the $\mathrm{p}$ value of .00 is far less than .05. Consequently, students of Medic ine have higher GE scores. In other words Medicine students are more successful in the ir GE courses. Table 6 provides a summary of these results.

\section{Table 6: A summary of the results}

\begin{tabular}{|l|l|l|}
\hline Medic ine students & internalizers & higher GE achievers \\
\hline Theology students & externalizers & lower GE achievers \\
\hline
\end{tabular}

\section{Intervie w Results}

The findings of the qualitative side of the study were almost in line with the results obtained from the questionnaires. Most Medicine students considered optimism about their future since relatively good job opportunities await them. Around $80 \%$ of these students held that their future jobs necessitate high command of English. Therefore, they believed that they should do their best to get high grade in their GE scores. For instance, one of them said," I am greatly motivated to learn English. I will try hard to obtain good competence in English." All in all, more than 70\% of Medicine students devoted more time to homework, were more adamant to get better grades in GE courses, and were more motivated to learn English. Last but not least, students of Medicine mostly highlighted the ir own efforts in achieving high scores.

In contrast, students of Theology were not as optimistic as students of Medicine. Almost half of them asserted that there are few job opportunities for them in future. Almost 70\% of these students had the belief that knowing English is not a vital part of the jobs they might find in future. As a result, most of them did not have high levels of motivation to learn English in general, and to achieve good grades in the ir GE courses in particular. Thus, they did not spend much time on GE homework. Some of them even hated GE courses. Some of them stated that they did not like their majors. Due to poor performance at high school they had been forced to study humanities and then continue their studies in this field.

\section{Discussion}

The first research question of this study deals with the possible relationship bestrewn LOC and GE achievement. The second question is whether there exists a significant difference between students of Medicines and those of Theology $n$ terms of LOC. Finally, the last question concerns the possible significant difference between the two groups of univers ity students in terms of GE achievement. 
One of the findings of this study was that students of Theology have external LOC, while students of Medicine have internal LOC. This is in agreement with Ghonsooly and Elahi (2010). Students of Theology, like other humanities students, have probably experienced more educational failures. Bender (1995) held that if a student tries hard at school tasks, but frequently fails to get good grades, he or she will develop an external LOC over time. In Iran, studying Theology, like other fields of humanities, is less socially valued, and some of Theology students were probably forced to study the humanities due to their poor performance at high school. Later, they were coerced into continuing their studies in one of the majors related to the humanities. It is certainly fair to say that most of these students are not sufficiently interested in what they study. This lack of sufficient interest also may adversely influence their academic success at university. Ghonsooly and Elahi (2010) found that the students of humanities are less successful in their General English courses in comparison with the students of engineering and the students of sciences. As a result, it is reasonable to claim that the students of Theology, like other humanities students, have developed an external LOC. These students hold the view that they cannot control outcomes, so they do not accept the responsibility of their learning. In contrast, the students of Medicine have an internal LOC. Similarly, it is in line with Author and Elahi (2010) who found that students of engineering and sciences are internalizers. It can be inferred that due to more social values attached to what they study, they are more motivated to study as hard as they can. This will lead to more success, which in turn, breads more motivation. Consequently, these students have developed an internal LOC over time. Unlike students of Theology who are externalizers, students of Medicine believe that they can controls outcomes, so they accept the responsibility of their learning

The other finding of this study is the strong link between students' LOC and their academic achievement in general, and GE achievement in particular. This is in agreement with Galjes and D'Silva (1981), Gifford, Mianzo, and Briceno-Perriott (2006), Wood, Saylor, Cohen (2009), Hadsell (2009), and Author and Elahi (2010). Ducette and Wolk (1972) concluded that those with internal locus of control show more persistence. Morris and Messer (1978) also found that internalizers have more academic task persistence. Kernis (1989) similarly found that individuals, who are internally controlled, are more task-oriented. This may explain the fact that students with internal locus of control devote more effort to and spend more time on their academic tasks that leads to more academic success.

Students of Medicine as internalizers hold the belief that they have control over what happens to them, whereas Theology students, who are externalizers, attribute their success or failure to external causes such as task difficulty or luck. Basgall and Snyder (1988) held that these students believe that there is no use in trying because their efforts are fruitless and they are doomed to failure. This is in line 
with the results of interviews in which students of Theology considered almost a gloomy future for themselves. Hence, they are not motivated to work hard to achieve academic success in general and to get good grades in GE courses in particular. Similarly, frequent use of external attributions makes them lose their motivation to progress (Basgall \& Snyder, 1988). On the other hand, Medicine students, as internalizers, hold that they can control their learning, so they have more motivation to cope with the problems they face in the process of their learning (Dornyei, 2005). Since internalizers believe they can control the ir learning, they accept the responsibility of their learning, and this makes them more motivated to work hard which leads to success. In the same vein, the results of the interviews indicated that Medicine students are more motivated to learn English, take GE course more seriously, and spend more time on GE course.

In order to explain the high GE achievement of L2 Medicine students we can also resort to the Motivational Self System put forward by Dornyei (2005). This model incorporates three dimensions: (1) ideal L2 self, (2) ought-to L2 self, and (3) L2 learning experience. Ideal L2 self is that aspect of the ideal self that is related to the second language. "If the person we would like to become speaks an L2, the Ideal L2 Self is powerful motivator to learn the L2 because of the desire to reduce the discrepancy between our actual and ideal selves (Dornyei, 2005, p. 105). In a similar vein, the interviews carried out with the Medicine students showed that these students had a good elf-image of themselves. Most of them intended to become successful specialists and university professors. This pushed them to try harder than the Theology students. As a consequence, Medicine students' ideal selves stimulated them to make more efforts than the Theology students.

The fact that the Medicine students are more successful in GE courses can also be explained by attribution theory. According to Jarvis (2005) the most effective kind of attribution is when people ascribe their past success and failure to internal factors such as effort. Thus, in light of attribution theory, students who are internally controlled, have more motivation to be successful in their academic tasks. The interviews conducted with Medicine students also revealed that these students highlighted their own efforts as an important requirement of success in language learning. Hence, they were more motivated to achieve high scores in GE courses. In contrast, the students of Theology, who are externalizers, give up to chance and fate because they see their future out of their control and gloomy (Anderman \& Migley, 1997).

\section{Conclusion}

The results of this study showed that there is a close link between LOC and GE scores of university students suggesting that LOC is an affective factor in EFL 
learning. Furthermore, there is a significant difference between the students of Medicine and those of Theology in terms of LOC. Finally, there is a marked difference in GE achievement between these two groups of university students. ESP practitioners may pay special attention to these findings.

Locus of control is a dynamic construct rather than a fixed one. Noer et al. (1987) held that externalizers can be taught to develop internal LOC. ESP teachers can instill a sense of responsibility in their students to take control of their own learning and become independent and self-directed learners .This is particularly important about the students of Theology who have external LOC. The most effective way to apply attribution theory is reattribution training (Hastings, 1994, cited in Hosseini \& Elahi, 2010). Therefore, ESP teachers should help these students change their attributions. Students should learn to ascribe their failures in English exams to factors such as their effort and ability that are controllable. They ought to be taught not to attribute the ir failures to factors like chance or test difficulty which are not controllable. Reattribution training should pay special attention to these students. According to Neurolinguistic programming, the behavior and strategies used by successful people can be duplicated (Richards, \& Rogers, 2001). Hence, suggestions and strategies employed by internalizers can be introduced to externalizers. They can be encouraged to model the suggestions and strategies employed by internalizers. Furthermore, increased awareness of LOC orientations can help students recognize what is within their ability to change and how to deal with factors they consider as beyond the ir control (Wood, Saylor, \& Cohen, 2009). Knowledge of the influence of internal and external orientations on students' attitudes, perceptions, and performance can be a great help for curriculum planning and the selection of teaching methods and materials. Apart from psychological factors, there are some sociological concerns that should be taken into account. Without a shadow of doubt, teachers' explanations and suggestions do not always work. Authorities should provide satisfactory job opportunities for graduates of Theology. This would spark more motivation in them to be more successful in the ir major and become more successful L2 learners.

In order to carry out any kind of research, one may confront problems and limitations. Almost different findings could be obtained in this study if it did not have the following limitations. First, this study was carried out with a relatively small sample. Studies with larger samples can be done to ensure the external validity of the findings. The second limitation of the research was that only university students in Mashhad participated in it. Other research projects can be conducted with students studding at other universities in other cities of Iran. Moreover, further studies can be undertaken to compare LOC and GE achievement in other groups of university students studying different fields. Further research can 
examine the relationship between teachers' LOC and their motivation and the ir student' performance.

\section{References and notes:}

Anderman, L. H. and Midgley, C. (1997). Motivation and midd le school students. In Judith L. Irvin. (Ed.). What current research says to the middle level practitioner, 1-48, Colu mbus, OH: National Middle School Association.

Basgall, J. A. and Snyder, C. R. (1988). Excuses in waiting: External locus of control and reactions to success-failure feedback. Journal of Personality and Social Psychology, $54,656662$.

Bender, W. N. (1995). Learning disabilities: Characteristics, indentification, and teaching strategies. (2nd Ed.). Needham Heights, Mass: Allyn \& Bacon.

Biaggio, A. M. B. (2004). Relationships between state-trait anxiety and locus of controlexperimental studies with adults and children. International Journal of Behavioral Development, 8 (2), 153-166.

Carden, R., Bryant, C. and Moss, R. (2004). Locus of control, test anxiety, academic procrastination, and achievement among college students. Psychological Reports. 95 (2), 581582.

De Raad, B. (2000). Differential Psychology. In Kazdin, A. E. (Ed.), Encyclopedia of psychology, Oxford: American Psychological Association and Oxford University Press, 3, 41-44.

Dornyei, Z. (2005). The Psychology of the language learner: Individual differences in second language acquisition. Mahwah, N.J.: Lawrence Earlbaum.

Ducette, J. and Wolk, S. (1972). Locus of control and extreme behavior. Journal of Consulting and Clinical Psychology, 39, 253-258.

Duttweiler, P. C. (1984). The Internal Control Index: A newly developed measure of locus of control. Educational and Psychological Measu rement, 44, 209-221.

Ellis, R. (2008). The study of second language acquisition (2end ed.). Oxford: Oxford University Press.

Findley, M. J. and Cooper H. M. (1983). Locus of control and academic achievement: A 1 iterature review. Journal of Personality and Social Psychology, 44 (2), 419-427.

Galjes, I., \& D'Silva, C. (1981). Locus of control and achievement of Nigerian school-age children. Journal of Psychology, 109, 199-204.

Ghonsooly, B., \& Elahi, M. (2010). Validating locus of control questionnaire and examining its relation to general English achievement. Journal of Teaching Language Skills, 2(1), 117-143.

Ghonsooly, B. and Pishghadam, R. (2008). Criticism of GPE courses at the university: The analysis of book exercises in the light of learning styles. Unpublished Project, Ferdowsi University of Mashhad.

Gifford, D., Mianzo, F., \& Briceno-Perriott, J. (2006). Locus of control, academic achievement, and retention in a sample of university first-year students. Journal of College Ad mission, 18-25.

Hadsell, L. (2009). Achievement goals, locus of control, and academic success and effortin introductory and intermed iate microeconomics. Paper to be presented at the ASSA 
Annual Meetings Session sponsored by the AEA Committee on Economic Education Atlanta, GA.

Hastings, N. J. (1994). Enhancing motivation in the classroom: Strategies for intervention. Educational and Child Psychology, 11 (2), 48-55

Horwitz, E. K. (2000). It ain't over till it's over: On foreign language anxiety, first language deficit, and the confounding of variables. Modern Language Journal, 84 (2), 256-259.

Hosseini, A., \& Elahi, M. (2010). On the alleged relationship between LOC, L2 reading achievement, and use of language learning strategies. Ferdowsi Review, 1, 21-47.

Jarvis, M. (2005). The psychology of effective learning and teaching. Cheltenham: Nelson Thornes Ltd.

Kernis, M. H. (1984). Internal versus external attributions are important determinants of subsequent performance. (ERIC Document Reproduction Service No. ED 195326 ).

Lefcourt, H. M. (1976). Locus of control: Current trends in theory and research. Hills dale, N. J.: Erlbaum.

Lonky, E. and Reihman, J. (1980). cognitive evaluation theory, locus of control and positive verbal feedback. (ERIC Document Service No. ED 195 324).

Macaro, E. (2009). Developments in language leaning strategies. In Cook, V. and Wei, L. (Eds.), Contemporary applied linguistics, London: Continuum International Publishing Group, 10-37.

Morris, S., \& Messer, S. (1978). The effect of locus of control and locus of reinforcement on motivation in the work performance of black managers. Journal of IndustrialNational Middle School Association.

Noel, J. G., Forsyth, D. R. and Kelley, K. N. (1987). Improving the performance of failing students by overcoming their self-serving attributional biases. Basic and Applied Social Psychology, 8, 151-162.

Oxford, R. and Ehrman, M. (1993). Second language research on individual differences. Annual Review of Applied Linguistics, 13, 188-205.

Phares, E. J. (1976). Locus of control in personality. Morristown, N. J: General Learning Press.

Phares, E. J. (1979). Defensiveness and perceived control. In Perimuter, L. C. and Monty, R. A. (Eds). Choice and perceived control. Hillsdale, NJ: Erlbau m. 195-298.

Richards, J. C., \& Rogers, T. (2001). Approaches and methods in language teaching. Cambridge: Cambridge University Press.

Robinson, P. (Ed.). (2002). Individual differences and instructed language learning. Amsterdam: John Benjamins.

Skehan, P. (1989). Individual differences in SECOND-language learning. London: Ed ward Arnold.

Williams, M. and Burden, R. (1997). Psychology for language teachers. Cambridge: Cambridge University Press.

Weiner, B. (1979). A theory of motivation for some classroom experiences. Journal of Educational Psychology, 71, 3-25.

Weiner, B. (1992). Hu man motivation: Metaphores, theories, and research. Sage: Thousand Oaks CA. 
Wood, A. M., Saylor, C., \& Cohen, J. (2009). Locus of control and academic success among ethnically diverse Baccalaureate nursing students. Nursing Education Perspectives, 30(5), 290-294.

\title{
SUMMARY
}

\section{A Comparison of Locus of control and General English Achie vement in Students of Medicine and Theology}

\author{
Seyyed Ehsan Golparvar
}

\section{University of Tehran, iran}

Locus of control refers to individuals' orientation to attribute their successes and failures. Its effect on students' academic achievement has scarcely been investigated within General English context. This study is aimed at exploring the difference in General English (GE) achievement between students of Medic ine and Theology. It also examines the effect of locus of control (LOC) on GE achievement in these two groups of university students. University students' General English scores serve as criteria for General English achievement. Fifty students of Medicine and fifty students of Theology participated in this study. The results of the study indicate that: (1) there is a significantly positive association between university students' LOC and their GE achievement, (2) there is a significant difference in GE achievement between students of Medicine and Theology, and (3) there is a significant difference in LOC orientation between these two groups of university students. The results of the interviews conducted with the participants were also in line with those of the questionnaires. The findings of this study suggest that developing internal control orientation can be very constructive in getting better grades in GE courses.

Keywords: Locus of control, internal, external, general English achievement. 